Meta

Journal des traducteurs

Translators' Journal

\title{
Sex, Lies and TV: Censorship and Subtitling
}

\section{Gabriela L. Scandura}

Volume 49, numéro 1, avril 2004

Traduction audiovisuelle

Audiovisual Translation

URI : https://id.erudit.org/iderudit/009028ar

DOI : https://doi.org/10.7202/009028ar

Aller au sommaire du numéro

\section{Éditeur(s)}

Les Presses de l'Université de Montréal

ISSN

0026-0452 (imprimé)

1492-1421 (numérique)

Découvrir la revue

\section{Citer cet article}

Scandura, G. L. (2004). Sex, Lies and TV: Censorship and Subtitling. Meta, 49(1), 125-134. https://doi.org/10.7202/009028ar

\section{Résumé de l'article}

L'article suivant porte sur la censure et les programmes de télévision sous-titrés. Il comporte trois parties. La première décrit les raisons de la censure ainsi que l'autocensure. Dans la deuxième partie sont expliqués les différents types de censure avec des exemples de chacun d'eux. La troisième partie détaille les résultats d'une enquête sur la perception de la censure dans les sous-titres, la compréhension des erreurs de traduction et la réception des restrictions telles que l'espagnol de l'Amérique latine de la part du public. 


\title{
Sex, Lies and TV: Censorship and Subtitling
}

\author{
GABRIELA L. SCANDURA \\ Asociación Argentina de Traductores e Intérpretes, Buenos Aires, Argentina \\ gls@anunciar.com
}

\begin{abstract}
RÉSUMÉ
L'article suivant porte sur la censure et les programmes de télévision sous-titrés. Il comporte trois parties. La première décrit les raisons de la censure ainsi que l'autocensure. Dans la deuxième partie sont expliqués les différents types de censure avec des exemples de chacun d'eux. La troisième partie détaille les résultats d'une enquête sur la perception de la censure dans les sous-titres, la compréhension des erreurs de traduction et la réception des restrictions telles que l'espagnol de l'Amérique latine de la part du public.
\end{abstract}

\begin{abstract} American' Spanish.

\section{MOTS-CLÉS/KEYWORDS}

censorship, subtitling, self-censorship, audience awareness, television
\end{abstract}

The following article deals with censorship and subtitled television programs. It is divided into three parts. The first part describes the reasons for censorship, including self-censorship. The second part explains the different types of censorship and gives examples of each, and the third part tries to explain the findings of a survey regarding audience awareness of subtitling censorship and reception of restrictions such as the use of a 'Latin

\section{Introduction}

When we talk about subtitling, its constraints usually come to mind: text compression, change of mode, etc. But it is not so usual to think of censorship as one of the restrictions imposed on subtitling.

Censorship is defined by the Cambridge International Dictionary of English as "the practice of examining books, films, etc. and removing anything considered to be offensive, morally harmful, or politically dangerous." In the case of media translation, censorship is sometimes present when dubbing and subtitling mask the deletion or replacement of erotic, vulgar or inconvenient sentences, allusions or references. But the most interesting aspect of censorship is perhaps the fact that it occurs not only when external sources like governments, distribution companies or networks force a show or movie to change something or translators to replace certain parts of their translations in order to adhere to what they consider "politically correct," but also when translators become self-censors by being unaware of sexual connotations, puns on words, taboo elements, etc. or when, in spite of being aware of them, they still decide to modify them to "protect the audience." Actually, there is a wide range of censoring activities, from deleting a scene to changing the language to a non-vulgar one, to omitting references or directly changing the whole plot (cf. Gambier, forthcoming).

When watching subtitled material, audiences often feel they are being cheated because they realize that what was said could not have been what was written in the 
subtitles, since images which are quite "hot" are matched with words that seem to have been taken from children's books. "The feedback-effect from the original whether that consists of recognizable words, prosodic features, gestures, or background visuals - may be so strong that (...) the friction between original and subtitle causes noise, and the illusion of the translation as the alter ego of the original is broken." (Gottlieb, 1994: 268) After all, a person who does not understand a certain language might know a few words in that language. Moreover, even if viewers do not understand the language of the original, the images are so obvious that they will consider any 'proper translation' wrong (if you see two criminals fighting, you know they will not be polite when shouting at each other!)

\section{Reasons for censorship}

Throughout history, censorship has been imposed on all means of communication: from books to newspapers, radio, TV, cinema, etc. "In subtitling, it is important to study what is transformed and why." (Gambier, 1994: 278) One of the reasons for certain transformations is censorship, and in turn there are many reasons for censorship. Of the many reasons why a movie or TV program may be censored, the most common ones have been:

a) Politics: Certain governments felt it was easier to rule their citizens by not letting them know about other cultures (and their ways of thinking). Thus, dubbing was used to hide the real sound of movies so that a new text could replace the original one, which was not always favorable to governments. Subtitling, on the other hand, is supposed to allow the viewer who speaks the language of the original to understand the right message.

b) Politically correctness: In the United States, for instance, Ellen, a sitcom about a woman who turned out to be a lesbian, was practically forced off the air in May 1998 after a "coming out" episode which aired too much controversy the previous year. (Meanwhile, it is apparently correct for you to watch Jackass on MTV, where "Johnny Knoxville and his team of sidekicks perform silly pranks, idiotic stunts, and other stupid stuff" [description of the site in Yahoo!], like shooting himself with a .38!). In Australia, a court recently decided that "fuck" is no longer a rude word, so now that it is politically correct, it can be used in any TV program. And in line with this concept of politically correctness, parents can also censor what their children watch on TV by using the V-chip or a device called "the TVGuardian," which filters profanity from videos, TV, DVD, satellite and cable while you watch, and even has Strict and Tolerant filter settings and modifies the close captioning by removing foul language.

c) Religion: In India, for example, some scenes from an American movie showing people drinking whisky had to be re-shot substituting milk for whisky because alcohol is forbidden by religion, and this extended to showing it on the screen. There is a fourth reason, which relates to translators:

d) Self-censorship: Sometimes it is the translator who decides to modify certain elements because he or she feels they are not appropriate. Translators tend to think they should protect the audience, and so they believe they can determine what is right or what is wrong to communicate, regardless of what the spirit and manner of the original were. For example, in one episode of Friends, Rachel and Monica are trying 
to get their apartment back, which they lost to Joey and Chandler while playing a game. When they finally get desperate, Monica tells the boys that she and Rachel will kiss for one minute in order to get their apartment back. The boys agree. The making out is never shown and the episode continues with another scene in which Joey tells Ross "Monica and Rachel made out." The translator must have thought that it was not appropriate for two girls to make out, but that it was all right for them to kiss their male friends, since the subtitles read "Rachel y yo los besaremos por un minuto" (Rachel and I will kiss you for one minute) and "Monica y Rachel nos besuquearon" (Monica and Rachel kissed us).

On the other hand, Lung (1998) suggests the translator's ignorance of idioms or of the foreign culture may cause mistranslation or undertranslation; thus, the translator also becomes a self-censor. In this case, the problem may be that the translator did not know exactly what "make out" meant, or did not realize that "make out" is an intransitive verb, so never realized he or she was changing the meaning to a "politically correct" one. Another instance of mistranslation or undertranslation may occur when the translator's ability to analyze discourse fails. The following example is also taken from Friends:

MONICA: I bought some shares of CHP and ZXY.

JOEY: How come those?

MONICA: Well, CHP because I used to have a crush on Eric Estrada. And ZXY because I think it sounds zexy.

RACHEL: What happened to MEG?

MONICA: MEG was good for me but I dumped her. Ya know, my motto is get out before they go down.

JOEY: That is so not my motto.

The joke is based on the words associated with breaking up a relationship, and it ends with Joey's (usual) reference to sex. Now the translator missed the point, since he or she did not realize this and translated the last sentences as "Me fue bien pero me salí. Mi lema es: Sácalo antes de bajar" (It was OK, but I got out. My motto is: Take it out before going down).

A similar kind of censorship (either whether the translator is aware of it or not) is the omission of references and allusions. In some cases it might be acceptable - for instance, if the original gives an example of something good that with time has become bad (e.g. an old documentary with a reference to Bill Bixby and Frank Zappa defeating cancer when you know that they finally died of it). In those cases, the omission or modification is - in my opinion - acceptable and even the translator's duty. If the translator does not change or omit the reference, the response produced will be just the opposite.

But in other instances, the omission is a mistake, which can be caused by a) the translator's lack of adequate knowledge; b) the fact that the translator underestimated the audience, and c) the translator's failure to realize that was a reference.

The problem in the first case is just a question of translators improving their knowledge of the language, of slang, of the source and target cultures, and of their ability to analyze discourse. As far as the second case is concerned, why should we leave every local reference out of the translation? It is true that some things may not be 
understood, but we should not underestimate the viewers. We translators are not the only ones who analyze discourse. Take, for instance, the following example from The Nanny: Fran tells Maxwell about a bald spot on the back of his head, and she says: "When you go out in the sun, you might wanna smear a little Coppertone on it." Even if the target culture audience does not know what Coppertone is, they will probably infer it is a product that protects skin from the sun.

Finally, there is one instance in which even the best translator may unknowingly and involuntarily make a mistake - when they are faced with an indirect reference they do not know. In an episode of Sex and the City, one of the characters says: "Cannolis and cream puffs and tarts, oh my!," whose intertextuality takes us to The Wizard of $\mathrm{Oz}$ ("Lions and tigers and bears, oh my!"). Having seen the movie many years ago, when I was a child, I did not see the intertextuality. (Actually, it was a student of mine who had lived in the United States for six years when she was a young girl the one who noticed the intertextuality.) The fact that it is impossible for the translator to know every possible indirect reference or allusion probably makes the audience miss some of them, but then we come to another important fact: not all references are worth keeping. However famous The Wizard of $\mathrm{O} z$ may be, most members of the audience in Latin America (except those who understand English very well, have seen the movie and remember the text - probably not many!) will not associate the sentence with the movie, so it would be useless - again in my opinion to try to explain in some way in the subtitles that the quotation comes from The Wizard of $\mathrm{Oz}$ or to use any other technique to get the audience to remember something they will probably not recall. That kind of omission, then, may be acceptable, but it depends on a thorough analysis of the audience's social and educational background on the part of the translator - and ultimately on the translator's knowledge of the indirect reference or allusion.

When translators recognize a reference, it is difficult for them to decide whether to keep it or not because there are no ironclad rules. "Any translation strategy is situation-specific." (Lung, 1998: 105) This is a dialogue taken from The Nanny:

MA: Doctor, can you make me look like this?

FRAN: Linda Evangelista, Ma? He's not Dr. Bombay.

Viewers in Latin America are likely to know who Linda Evangelista is, but not Dr. Bombay (a character from an old TV show called Bewitched). Therefore, the translator will probably be forced to keep the first reference and change the second one.

In any case, what the translator should remember is that the aim of watching TV is not only being entertained but also learning, and there is nothing as useful in this world as learning about other cultures. If we remove everything we consider vulgar, not significant or too local, we are cheating the audience, and we are even preventing them from learning.

\section{Types of censorship imposed on subtitling}

Apart from the instances in which the translator becomes a self-censor due to inadequate knowledge of the language and culture or because he feels like Big Brother, there are different types of censorship imposed on the subtitling of TV programs: 
a) Changing the title/subtitles of a program: If the distribution company considers a title not attractive enough, they will change it. Sometimes the translator is consulted; other times not. Sometimes subtitles are changed without consulting the translator, and that may lead to mistakes because the editor who corrects the subtitle is unaware of a certain allusion or a certain decision taken by the translator to adapt the text for cultural reasons.

Many people have complained about the changing of titles in Latin America, since they can compare them to the original ones. For some reason, it is usual in Latin America for movies to have a name that differs from the English title, a tendency which does not exist in Spain. Consider these examples:

\begin{tabular}{|c|l|l|}
\hline NAME IN ENGLISH & $\begin{array}{l}\text { NAME IN SPANISH } \\
\text { (LATIN AMERICA) }\end{array}$ & $\begin{array}{l}\text { NAME IN SPANISH } \\
\text { (SPAIN) }\end{array}$ \\
\hline Silence of the Lambs & $\begin{array}{l}\text { El silencio de los inocentes } \\
\text { (Silence of the Innocent) }\end{array}$ & $\begin{array}{l}\text { El silencio de los corderos } \\
\text { (Silence of the Lambs) }\end{array}$ \\
\hline Insomnia & $\begin{array}{l}\text { Noches blancas } \\
\text { (White Nights) }\end{array}$ & $\begin{array}{l}\text { Insomnio } \\
\text { (Insomnia) }\end{array}$ \\
\hline The Accidental Tourist & $\begin{array}{l}\text { Un tropiezo llamado amor } \\
\text { (A Mishap Called Love) }\end{array}$ & $\begin{array}{l}\text { El turista accidental } \\
\text { (The Accidental Tourist) }\end{array}$ \\
\hline The Contender & $\begin{array}{l}\text { La conspiración } \\
\text { (Conspiracy) }\end{array}$ & $\begin{array}{l}\text { Candidata al poder } \\
\text { (Candidate for Office) }\end{array}$ \\
\hline The Green Mile & $\begin{array}{l}\text { Milagros inesperados } \\
\text { (Unexpected Miracles) }\end{array}$ & $\begin{array}{l}\text { La milla verde } \\
\text { (The Green Mile) }\end{array}$ \\
\hline
\end{tabular}

This habit of changing names also applies to TV programs (The Six Million Dollar Man was called The Nuclear Man), where the part of the opening sequence in which the title of the show appears is cut and replaced by the new name in Spanish; this "cut and paste" technique becomes annoyingly apparent to the audience. For instance, The $X$ Files, whose translation for cable TV was Los expedientes secretos $X$, was translated as Código X on open TV, and the image where the words "The X Files" appeared was replaced by a similar image that read "Código X." This tendency is gradually disappearing, since cable TV channels are leaving the names of programs and movies in English (although this could also be an instance of censorship, because people who do not understand English do not know what the title means; you can use a name like Will \& Grace or That 70's Show in Spanish, but what about Whose Line Is It, Anyway? Cable TV channels that use subtitling know that people who watch their programs know English, but I think they are also leaving those who do not behind, for I doubt they would be attracted to a show with a name they cannot understand or even pronounce.

b) Changing the plot: This can usually be done when dubbing a program, but it could also apply to subtitling. The Nanny, a sitcom about a Jewish bridal shop salesgirlturned-nanny who takes cares of the children of a rich Broadway producer from Britain, was completely modified in Italy “to fit the audience." Writer Guido Leone, who had already transformed Rosanne Barr into a Neapolitan, was in charge of the Italian "adaptation." Fran became Francesca and was no longer Jewish-American but Italian. Ma Sylvia and her husband Mortie became Assunta and Antonio Cacace, Fran's aunt 
and uncle, and Granny Yetta became Assunta's sister-in-law. The reason, according to Simonetta Minini, from TV Sorrisi e Canzoni, was that Italians would not have accepted older women longing for sex. The "adaptation" would even include a Jewish wedding turned into a Catholic one. In spite of all these changes, some Italians didn't mind these modifications, but others felt these reasons were totally absurd and would have preferred to see the original version. In short, the "adaptation" was simply a euphemism for "censorship," since all the Jewish elements disappeared completely from the show.

c) Toning down strong language: A typical instance of censorship in Latin America is the usual habit of forcing translators to tone down strong language, i.e. substituting vulgar words for neutral ones (for example, using "penis" or "making love" instead of other slang expressions with the same meaning). In Latin American cable TV it is difficult to find subtitles with strong or vulgar language. (However, the same cable channels show soft porn and movies in Spanish with foul language).

Roffe and Thorne (1994: 258) argue that written foul language is "more offensive than actual oral usage," and so translators are usually asked to respect "a certain sanctity attached to written discourse in our culture. While one of the writer's tasks might be said to be to transgress certain taboos, (...) the translator must respect norms of good usage (avoiding elements considered extremely vulgar or offensive if they appear in written discourse)." (Gambier, 1994: 280) It might be argued that this is the reason why foul language is toned down, and I agree that extremely rude language should be avoided, but that does not mean we should neutralize and sterilize every single vulgar word, since in doing so we would risk producing a laughable effect.

One example of this type of tone-down censorship is the translation of Sex and the City. It is a show about four single women in New York who are always looking for guys, and although it is "well written" (as Dorothy Rabinowitz stated in The Wall Street Journal), it has been described as shallow, vulgar and decadent (Marianne Jennings suggests "Sluts in Stilettos would have been a better name for this silly series"). Sex and the City airs on HBO, which is a premium channel, and this means it is free from censorship. So it is ridiculous to ask the translator to tone down the vulgar language in the show, since it is obvious that these women employ "the language of longshoremen." The viewer can easily realize that this is not the language used by the people in the show. The program usually relies on word puns, repetitions, allusions, and understatements to convey humor. In fact, its fine writing is what makes it so difficult for translators to neutralize the language. There is an episode about a man who has one of his testicles surgically removed that plays with the word "balls" throughout the script. The constraint of not being able to use the right (slang) word in Spanish makes it difficult to use the same word every time the word "ball" appears.

There are other more subtle ways of neutralizing language. One such case is typical of the translation of The $X$ Files. The $X$ Files is quite a formal program, so much so that David Duchovny (Special Agent Fox Mulder) once said that he was happy he was doing a movie because he would get to swear. Damian Duffy comments on his website (<www.illinimedia.com/buzz/spring_2001/20010329/tv1.html>) that on The X Files, "Robert Patrick's character John Doggett is supposed to be a hardbitten ex-New York cop. But he has to call UFO stories "B.S." That's not how a New York cop is going to talk, and for a program that requires the realism of its characters to balance out the far-fetched sci-fi plotlines, this kind of B.S. is a terrible strain on 
storytelling." Accordingly, the translation of The X Files is very prim and proper. That would be totally acceptable, since it would respect the principle of retaining the style of the original. But when it comes to certain subtleties regarding Duchovny's character, it goes far beyond prim and properness. It is definitely censorship. Every sexually suggestive reference regarding Mulder, for instance, becomes toned down, and even his wry comment about the procedure to donate his sperm for Scully's in vitro fertilization in one of the series' turning point scenes was neutralized:

SCULLY: Well, I'll call Dr. Parenti and... I assume that he'll want to meet you and go through the, uh, the donor procedure.

MULDER: At that part, I'm a pro.

In the translation, the emphasis on the word 'pro' disappeared.

This example is taken from a Christmas episode in which Mulder is talking to a ghost:

GHOST: 'Cause you're a lonely man. A lonely man chasing paramasturbatory illusions that you believe will give your life meaning and significance and which your pathetic social maladjustment makes impossible for you to find elsewhere.

MULDER: "Paramasturbatory"?

"Paramasturbatory illusions" was translated as "placer paranormal" (paranormal pleasure). The deletion of the word "masturbatory," perhaps thought to be too direct, reflects the way these words related to sex were usually omitted or toned down.

\section{Audience awareness of censorship}

The most surprising thing about censorship is that viewers don't always reject it. In fact, in some cases they are quite happy with it, as was the case with the transformation of Fran Fine into Francesca Cacace. Another interesting thing to analyze is the fact that many cable TV channels, for instance, don't realize that subtitling does not mask the real message as easily as dubbing. The case of Sex and the City mentioned above is quite striking. It is obvious to the audience that the level of the language used is being modified, but they may think that it is the translator who chooses to turn an insult into something much lighter instead of the network or cable channelturned-censor that decides what is wrong for the audience to read.

A small-scale survey about subtitling and censorship was conducted in August 2002 inside a multiplex in Buenos Aires, Argentina. Questions included the person's age, education level, and favorite cable TV channel, as well as more specific questions such as whether they preferred subtitling or dubbing, if they could recall a good and/ or bad translation, if they liked the use of a "Latin American" Spanish and why they thought insults were replaced by politically correct versions in translations. The findings were very interesting. In some cases, they confirmed what has already been said about audience preferences; in others, the results were really unexpected.

- Younger people (18-45, most of them with university degrees or studying at university) preferred channels devoted to movies and sitcoms, which are subtitled. Older people (who tend to be slower readers) preferred documentary channels, which use the voice-over technique.

- $63 \%$ of those surveyed (mainly young people) preferred subtitling over dubbing, mainly because it allows them to listen to the original voices and lets them practice 
their English. If the original was not in English, then they preferred dubbing. Those who chose dubbing said subtitling interferes with the picture, and also mentioned the fact that they could do something else while listening to the program.

- Regarding the SAP (second audio program) system, only $26 \%$ said they used it, and only 1 person said he/she used close captions to be able to read the English version.

- An interesting 52\% of those surveyed said they could not recall either a good or a bad translation. Many of them were the ones who preferred dubbing, who also indicated they do not pay attention to the translation. On the other hand, the reasons given both for a good and a bad translation (all of them related to subtitling) were quite right:

- The translator probably did not know the source language as well as he/she should (20\%); one person even mentioned an example ("You should wax your chest" translated as "You should put some wax on your chest");

- The translator is not well paid (10\%);

- Big production companies have larger budgets and so they can get a "better" translation (actually, this might be related to the kind of script the translator is given);

- Keeping the subtitles source-oriented maintains the program's effect and spirit (particularly in the case of sitcoms);

- One person said the bad translation he/she could recall was in fact good, but too fast (which is actually an indicator of a 'bad' translation).

- Another person said the translation of The Nanny had many mistakes (this example confirms what I already suggested in a previous paper) (Scandura, 1999), while he/she favored the subtitling of The X Files not on TV but on video (where, as I pointed out above, there are no language restrictions).

- Regarding the reason for toning down strong language, those surveyed gave different reasons:

$-26 \%$ said they thought it was due to the fact that children could watch the programs, while another $25 \%$ said it was out of respect for the audience;

$-10 \%$ thought the legislation did not allow translators to use foul language

(only one person actually used the word 'censorship');

- 10\% believed Latin Americans were too "puritanical";

- The rest concluded they did not know why, but mentioned it was 'unnecessary' and 'changed the essence of the program.'

- As far as the use of a 'Latin American' Spanish is concerned, an astonishing 68\% said they did not mind its use; many of them were the ones who preferred dubbing to subtitling; one person said he/she actually liked it and another one highlighted the fact that it was supposed to reach all audiences in Latin America. Out of the 32\% who disliked the use of a Latin American Spanish, 3\% said they did not feel 'identified' with it; among them were the ones who had talked about censorship and disliked the habit of toning down strong language and 'changing the essence' of the program.

I think the most important facts to remember about these findings are:

- People who prefer subtitling to dubbing have a higher level of education and are younger. Most of them understand another language (mostly English). This is quite logical, since cable TV is relatively new and "people seem to prefer whatever method they were originally exposed to and have resultantly grown accustomed to." (Danan, 1991: 607) This confirms what is maintained by Luyken (Luyken, 1991: 38, 112). These people are the ones who pay more attention to translations because they compare them with the original sound. It is obvious that this tendency will not change, since young people - due to the availability of cable TV, SAP, DVD, and 
other new technologies that let them listen to the original sound - will have a greater knowledge of other languages (particularly English), will keep on comparing the subtitles with the original and will feel disappointed if translations are not what they expect.

- Nevertheless, over half of those surveyed (52\%) could not recall either a good or a bad translation. At first sight, this could be considered as a bad indicator, but one must wonder if it is really so, since most of the time translations are 'invisible.' Is it possible that the translations were so good that people did not realize they were translations?

- Another surprising outcome was the fact that $68 \%$ of those surveyed did not mind the use of Latin American Spanish, while for us translators, it has become some kind of nightmare, particularly when subtitling sitcoms, because it is virtually impossible to use a Spanish every country - or even every community - may identify with. Indeed, some translators oppose it because they view the obligation to use this kind of Spanish as another instance of censorship

\section{Conclusion}

There are still many aspects of subtitling that should be further analyzed. It would be interesting to study in future why it is that this protection of the audience only takes place on TV and not in cinema, and particularly why translators feel like some kind of V-chip and impose their self-censorship on TV programs (where they know they can) and not on movies shown in the cinema (where censorship does not usually occur). Is it because they have been taught that written discourse should not be as rude as the original spoken one? Could it be they consider TV is usually open to any kind of audience, and the cinema has a specific type of audience? Because in that case, they share the same belief audiences hold - that the restrictions on TV are out of respect for (mainly younger) audiences.

In any case, it is clear that it would be difficult to persuade networks and channels that censoring the language and not the images is ridiculous and that censoring the content of the programs might be considered an offense by the audience, because they do not seem to understand that the non-verbal behavior of the characters cannot contradict their words, for "both the visual channel and the acoustic channel are simultaneously utilized." (Delabastita, 1989: 196) Moreover, in the Internet and the Information Era it is silly to think that people will never realize what the original content and words were (consider this comment on an Internet site: "Both the Vchip and the G-string apply silly technical solutions to complex cultural phenomena, confident in their stupefying simplicity: sexy nude dancers with G-strings are no longer sexy nude dancers; inane offensive television sets with $\mathrm{V}$-chips are no longer inane offensive television sets"). (Burke) But first translators should be aware of the fact that their self-imposed censorship is actually robbing the audience of their chance of understanding and even learning about other cultures, other lifestyles, other realities.

Regarding the survey, further research, at a larger scale, should be conducted in Latin America to confirm or deny the findings of this small-scale survey, so that translators and companies could decide by consensus if some kinds of censorship might be applied when the audience is used to them, or if we should start changing now this incorrect habit of censoring because current young people (and the next generations as well), who know other languages and prefer subtitling to dubbing, 
oppose these restrictions and will demand that translations respect the original style of the show. And, to prove my point, let me finish with the words of one of the people surveyed: "I usually watch subtitled programs if they are in English, because I like to listen to the original voices and I can practice my English. If the movie is not in English, I prefer dubbing. But I always watch dubbed programs when I am with my parents."

\section{REFERENCES}

Burke, B.: The Moral and Political Significance of the V-Chip, Center for Educational Priorities, Covelo, California, <www.cep.org/vchip.html>.

Danan, M. (1991): “Dubbing as an Expression of Nationalism," META 36-4, pp. 606-614.

Delabastita, D. (1989): "Translation and Mass-Communication: Film and TV Translation as Evidence of Cultural Dynamics," Babel 35:4, pp. 193-218.

Gambier, Y. (1994): “Audio-visual Communication: Typological Detour," in Teaching Translation and Interpreting 2, Papers from the Second Language International Conference, Elsinore, June 4-6, 1993, Dollerup, C. and A. Lindegaard (eds), Amsterdam/Philadelphia: John Benjamins, pp. $275-283$.

GAmbier, Y. (forthcoming): “Les censures dans la traduction audiovisuelle," TTR, numéro spécial sur Censure et traduction, $14^{\mathrm{e}}$ Congrès annuel de l'ACT, Association canadienne de traductologie, 26-28.5.2000, Québec.

Gotтlieb, H. (1994): "Subtitling: People Translating People," in Teaching Translation and Interpreting, Dollerup, C. and A. Lindeganard (eds), Amsterdam/ Philadelphia: John Benjamins, pp. 261-274.

Jennings, M. (2000): "Sex and the City: The Shallow but Vulgar Female," <www.jewishworld review.com>.

Jung, R. (1998): "On Mis-translating Sexually Suggestive Elements in English-Chinese Screen Subtitling," Babel 44:2, pp. 97-109.

Luyken, G.-M. et al. (1991): Overcoming Language Barriers in Television. Dubbing and Subtitling for the European Audience, Manchester, The European Institute for the Media.

Scandura, G. (1999): “Wanna Translate Sitcoms? Gotta Read People Magazine!," in Traduction Transition, Proceedings of the 15th FIT World Congress, Mons, 6-10.8.1999, Paris, FIT, pp. 288295. 